\title{
Characteristics and distribution of trulli constructions in the area of the site of community importance Murgia of Trulli
}

\author{
Giuseppe Ruggiero, ${ }^{1}$ Stefano Dal Sasso, ${ }^{2}$ Rosa Viviana Loisi, ${ }^{1}$ Giuseppe Verdiani ${ }^{1}$ \\ ${ }^{1}$ Department of Agro-Environmental Science (DISAAT), Aldo Moro University of Bari; ${ }^{2}$ Freelance \\ Civil Engineer, Bari, Italy
}

\begin{abstract}
The agro-forestry territory in the Region of Apulia, southern Italy, is characterised by a widespread and diversified presence of dry stone constructions, including trulli, rural buildings with a characteristic a conical shape. The trulli are mainly to be found in the central and eastern part of the region, called Murgia of Trulli. Trulli are perfectly integrated with the agro-environment specificity of the area, creating a unique landscape and establishing themselves as a testimony of tradition and rural culture. In fact, in this area, from the $17^{\text {th }}$ until the mid$20^{\text {th }}$ century, the trulli accompanied the development of agricultural activities. According to the number of cones they had, they were used as temporary shelters, places of support for primary production, or comfortable houses for the rural population. In recent decades, for several social and economic reasons, this heritage of rural buildings has been affected by abandonment and degradation phenomena. Interventions aimed at recovery and re-use have not always respected the origin of the buildings, their design characteristics or the landscape in which they had been built. In order to reduce the impact that this situation has had on environmental and territorial quality it is, therefore, necessary to develop initiatives to protect and valorise the trulli while respecting the identity of place, the architectural elements, and the agricultural and environmental characteristics of the territory. For this purpose, we need to analyse and characterise the heritage of the existing trulli and its relationship with the local reality. The present paper analyses the typology and distribution of the trulli located on
\end{abstract}

Correspondence: Giuseppe Verdiani, Department of Agro-Environmental Sciences (DISAAT), Aldo Moro University of Bari, via Amendola 165/A, 70126 Bari, Italy.

Tel/Fax: +39.080.544.2960.

E-mail: giuseppeverdiani@hotmail.it

Key words: rural building, agroforestry territory, GIS analysis.

Contributions: the authors contributed equally.

Received for publication: 17 June 2013.

Accepted for publication: 21 September 2013.

(C) Copyright G. Ruggiero et al., 2013

Licensee PAGEPress, Italy

Journal of Agricultural Engineering 2013; XLIV:e13

doi:10.4081/jae.2013.e13

This article is distributed under the terms of the Creative Commons Attribution Noncommercial License (by-nc 3.0) which permits any noncommercial use, distribution, and reproduction in any medium, provided the original author(s) and source are credited. the site of community importance Murgia of Trulli, a protected area with high environmental value in the central-eastern area of the Region of Apulia. Specifically, we analysed the relationship between the trulli buildings and the agro-environment context to acquire a basic interpretative knowledge in order to define strategies for recovery and re-use.

\section{Introduction}

Rural buildings are material evidence that contribute to the definition of recognizable historical - anthropological unity, with particular reference to the link between settlement and agricultural production space (Italian Regulation, 2005). Indeed, there is a close correlation between rural buildings, local context, natural environment and agricultural activity (Banks and MacGregor, 2000; Picuno, 2012). In fact, the spread of rural buildings in agro-forestry territory has served the function of agricultural activities, storage and food product processing, and have very often provided a useful dwelling for agricultural workers and their families (Van Deer Vaart, 2005; Dal Sasso and Caliandro, 2010). The rural buildings also represent a considerable and widespread heritage with high historical and architectural value. They play an important part in the image of the rural landscape (Fuentes et al., 2010) and this image cannot be separated from the buildings that belong to it (Guercini and Ruggiero, 2009).

The agro-forestry landscape of the Region of Apulia is characterised by the presence of many types of farm buildings with high architectural and historical value associated with the agricultural vocation of the territory. In particular, throughout the Region, rural dry stone constructions with stone elements shaped by hand and without the use of binders are widespread.

A significant expression of rural dry stone constructions are trulli. They are to be found in various forms and types mostly in the Apulian agro-forestry territory (Dal Sasso and Giglio, 1994). The trulli were originally built as agricultural buildings and are a typical part of the local architectural heritage. They are extremely important from a historical and cultural point of view, and make a valuable contribution to the landscape and environment with their highly characteristic conical shape. Historical, cultural and social factors have all contributed to their diffusion. There are many hypotheses about the origin of the trulli. These range from the evolution of prehistoric huts that becomes petrified to the importation of oriental patterns of prehistoric origin (Dal Sasso and Giglio, 1994). From this latter hypothesis it appears that the architectural model of the trullo was imported by the Greeks when they colonised southern Italy, including Apulia, between the $8^{\text {th }}$ and $5^{\text {th }}$ centuries B.C. The Greek tholos construction, very similar to the trullo, is indeed a construction of truncated conical shape. It has a circular ground plan and is covered by rings of stone blocks that form a pseudo-dome. This particular building had a sepulchral use while the trullo 
was used as a rural dwelling and/or as a support for agricultural activities. The relationship between tholos and trullo is also reinforced by the common etymological matrix because the term trullos ( $\tau \rho \circ \widetilde{v} \lambda \lambda \mathrm{\circ}$ ) means dome in ancient Greek. Trulli are to be found in most part of the region and have different spatial density, shapes and typological characteristics. These differences are due to the environmental, geological and socioeconomic characteristics of the territorial contexts.

Most of the trulli are found in the area of south-east Murgia between the provinces of Bari, Taranto and Brindisi, and have forms of particular architectural value. This area is characterised by the presence of approximately 50,000 trulli (Giorgi and Speciale, 1989) with a spatial density that in some areas reaches 70 units/ $\mathrm{km}^{2}$ (Giglio, 1994). In this area, the trulli are made of limestone collected from the working of the fields and the excavations for the construction of rainwater harvesting cisterns (Allen, 1984). To build the trullo, the ground plan was traced directly on the ground (D'Aurea, 2008). According to the surface area of the rooms, the ground plan could be circular or square; a square ground plan would have the maximum diameter from the height and from the weight supported by the walls (Pagano and Guarniero, 1936). The foundations for the trulli were laid directly on bedrock regularised with stones mixed with a lean mortar made of lime and red soil or lime and clay. The thickness of the load-bearing walls varied between 0.8 and $3 \mathrm{~m}$ and were relatively low (1.6-2 $\mathrm{m}$ high). The walls were built without mortar. The inner wall was built plumb and the outer wall was well-squared and inclined inwards to provide stability for the building itself (Allen, 1984; Calò, 2007; D’Aurea, 2008). The space between the two walls (muraja) was filled with stones and a small amount of soil (Allen, 1984; Calò, 2007). Horizontal stones (the so-called chiattoni) were laid across the wall at regular intervals in order to make the structure solid (D'Aurea, 2008). The interior walls were typically plastered with lime to make the room bright and welcoming while at the same time keeping insects away (Calò, 2007). Niches and small alcoves were carved in the thick walls and these were used as cabinets and pantries. Articles and clothes were hung from the walls and arched alcoves were built to provide bedrooms. In the walls, small windows were opened with stone architraves. The front door, which typically faced east/south, had a wooden lintel surmounted by a well-prepared dry stone arch (Pagano and Guarniero, 1936; Notarnicola, 1940; Allen, 1984; D’Aurea, 2008). In trulli with a circular ground plan, the self-supporting dome was engaged directly onto the walls (Calò, 2007) while in trulli with a square ground plan the walls were gradually rounded towards the top to accommodate the dome (Allen, 1984; D'Aurea, 2008). However, in these cases, the dome starts with an elliptical shape that is gradually transformed into a nearly perfect circle as it rises (D'Aurea, 2008). The dome is $2-2.6 \mathrm{~m}$ in diameter and $0.5-0.9 \mathrm{~m}$ thick while the height was often exploited by making wooden mezzanines to be used for storage. The dome is self-supporting and is characterised by the overlapping of horizontal concentric rings of ashlars stuck between them (Allen, 1984) and is held together by a mixture of lime and bolus (red soil) (D'Aurea, 2008). On the dome, a roof of downward-sloping and overlapping limestone tiles called chiancarelle were mounted to facilitate rainwater runoff (D'Aurea, 2008). The rainwater was channeled and routed through a compluvium into the cistern below. In the areas where it was not possible to extract the chiancarelle the same blocks as for the walls were used and a lime-based plaster was used to waterproof the surface (D'Aurea, 2008). The dome apex was made from an ornamental stone pinnacle of various symbolic shapes (sphere, truncated cone, cross, disc) or by a horizontal removable stone element (D'Aurea, 2008) to allow air and light to enter from above and/or for the introduction of agriculture products (Ambrosi, 1990). The trullo obtained in this way can be considered a volumetric module, i.e. a cell construction capable of creating other buildings by budding and so becoming bicellular, tricellular, etc. (Zito, 2009). These form the so-called casali or groups of houses (Giorgi and Speciale, 1989). In south-east Murgia, some unicellular trulli may be found or otherwise they are often aggregated to form buildings consisting of more elements (multicellular trulli), trullaie (trulli complexes) and farms. In these cases, each module is aggregated into bigger complexes but maintains its own planimetric and spatial characteristics and identity. In the same building, the construction of more cones coincides with the different internal spaces (De Mandato, 1933 ) and the dome over the biggest room has the highest dome. Inside the multicellular building, the passage between the volumetric modules is created by arches while outside intersections within the volume of the dome are useful for the recovery of large amounts of rainwater. The ground plan of the multicellular trulli is always square because it would be impossible to combine two or more elements with a circular ground plan (Pagano and Guarniero, 1936).

The reasons that have determined the aggregation of trulli in this area are to be found primarily in the relationship between man and the environment, and in the evolution of anthropological needs such as: i) temporary or permanent shelter for agricultural and livestock needs; ii) shelter for farm equipment and animals; iii) spaces for activities related to the processing and storage of agricultural and livestock products.

In the aggregation evolutionary process it is possible to make a basic distinction depending on the demographic entity that uses the trulli and on the cultivation of the attached land. The less complex form, represented by the unicellular trullo, is typically used by a household (or their representatives) and is linked to temporary housing needs for the completion of farming activities over short periods of the year (harvesting, pruning, etc.). The bicellular or tricellular trulli represent the residence of a mono-family farmhouse permanently involved in polycultural activities and sometimes in small-scale livestock farming. Once we get to the 4-module ground plan we can start to speak of a farm (Allen, 1984) in which the single trullo acquires different forms and functions depending on the specific use made of it while remaining traditionally connected to a main family unit. These trulli can indeed be used as houses, barns or warehouses, integrated with ovens, cisterns, wells, and farmyards (often paved) which link the housing and complementary modules. Therefore, the trulli farms enhance their multi-functionality also due to the large and extensive agrarian areas that are connected together and thanks to the significant livestock activity that takes place.

Some areas of south-east Murgia, are characterised by a high spatial concentration of trulli buildings such as the rural districts and the entire town of Alberobello. The historical centre of Alberobello is, in fact, consists only of trulli and this feature makes it one of the most important residential complexes of rural architecture in the whole Mediterranean basin (Cardinale et al., 2013). The high trulli density, their aggregation and integration with the dense texture of dry stone walls, and the mosaic agriculture (secular olive groves, arable land, wooded bands, Mediterranean scrub) have generated a landscape with a strong agro-environmental connotation that is often defined as that of a fairy-tale due to the characteristics of these buildings. For this reason, a large part of Murgia called Murgia of Trulli has been recognised by the Landscape Plan of the Region of Apulia (Puglia Region, 2000) as a landscape with specific physical-environmental, historical and anthropic characteristics. The area of Murgia of Trulli includes municipalities shown in Table 1.

The trulli presence in the area of the Murgia of Trulli, as well as being of great value to the landscape, is also historical evidence of the socioeconomic evolution of agricultural society. Over the last 50-60 years, the changes in Italian and European agriculture have meant that the agricultural function of the trulli has become less important and they have often been adapted to new socio-economic use or have been abandoned. However, some trulli are still permanently in use by farmers, but there are many others that have lost their age-old agricultural identity and 
have been used for many different things. Abandoned trulli in a state of disrepair and trulli used for seasonal agritourism activities, often affected by recovery interventions that are not always respectful of the landscape and design characteristics, are also to be found. Problems of recovery of the trulli buildings are due to the difficulties in finding skilled labour, the high maintenance costs compared to the lower cost of reconstruction, and the difficulties of adapting the trulli to the changed conditions of use (Giglio, 1994). The trulli buildings were often not very comfortable to live in because of the lack of water and of a gas supply for fuel, the absence of any sewerage system, the small size of the windows that do not provide adequate indoor ventilation, and the unsuitable reduced volumes that do not satisfy housing needs.

These features mean that the trulli often do not comply with requirements for residential use and require proper hygienic-sanitary and structural consolidation and enlargement. These may allow multicellular trulli to be re-used for agricultural, residential or agritourism purposes but it is often more difficult to recover single-cell trulli and those with small interiors $(6-8 \mathrm{~m})$.

In such a scenario, it is useful to know the number and types of aggregation of trulli and their spatial distribution with respect to the main agri-environmental components to be able to create a framework for possible re-use. There are many trulli buildings within the environmental boundaries of the Murgia of Trulli of a site of community importance (SCI) and this has led to recognition of the need for a technical and scientific study of the relationship between the protected area, agriculture and trulli. This SCI area, Murgia of Trulli, has a surface area of 5457 ha and includes part of the towns of Alberobello, Castellana Grotte, Fasano, Locorotondo and Monopoli (Table 2 and Figure 1).

The aim of the work is to analyse the trullo building heritage in terms of architectural aggregation and spatial distribution to guide the choices of recovery for long-term re-use. More specifically, the study identified the different types of cone aggregation and assessed the existing relationships with the use of the adjacent land, the distance from other elements of cultural and environmental heritage, and from the road infrastructure. The punctual and analytical knowledge of the trulli is a preliminary means of safeguarding successful recovery, protection and enhancement of these rural heritage elements, for landscape planning and to promote an integrated and sustainable development that respects the SCI Murgia of Trulli.

\section{Materials and methods}

This study examined trulli buildings and their relationships with agro-environmental components in the SCI Murgia of Trulli. This analysis was carried out both in a GIS environment using the data collection, photo interpretation and geoprocessing operations, geoprocessing described below and through field surveys.

\section{Area of study}

The SCI Murgia dei Trulli was chosen for this study because of its important and valuable environmental and landscape features due to the widespread presence of trulli buildings, dry stone walls, agro-livestock characteristics and natural elements. The Murgia of Trulli (SCI IT 9120002) has been identified by the Region of Apulia with the Apulia Regional Council Resolution (DGR) no. 3310 of 23/07/1996 (Puglia Region, 1996) and instituted by the Decree of the Ministry of Environment of 03/04/2000 (Italian Regulation, 2000) for the presence of a sparse cover of autochthonous evergreen oaks (Quercus Trojan, Quercus ilex) in good condition which are an important habitat for birds of prey.

The Murgia of Trulli is located at the south-east extremity of the

Table 1. Murgia of Trulli (PUTT/p, Puglia Region, 2000).

\begin{tabular}{|c|c|c|c|}
\hline Municipalities & Province & $\begin{array}{c}\text { Surface within the Murgia } \\
\text { of Trulli, ha }\end{array}$ & $\begin{array}{l}\text { Surface within the Murgia of } \\
\text { Trulli/municipal total area, } \%\end{array}$ \\
\hline Alberobello & Bari & 4031 & 100 \\
\hline Carovigno & Brindisi & 2694 & 100 \\
\hline Castellana Grotte & Bari & 6677 & 99 \\
\hline Ceglie Messapica & Brindisi & 13,044 & 100 \\
\hline Cisternino & Brindisi & 5407 & 100 \\
\hline Crispiano & Brindisi & 1124 & 26 \\
\hline Fasano & Brindisi & 12,894 & 100 \\
\hline Gioia del Colle & Bari & 3277 & 16 \\
\hline Grottaglie & Brindisi & 106 & 100 \\
\hline Locorotondo & Bari & 4752 & 100 \\
\hline Martina Franca & Taranto & 29,531 & 100 \\
\hline Massafra & Taranto & 3215 & 26 \\
\hline Monopoli & Bari & 15,666 & 100 \\
\hline Mottola & Taranto & 13,668 & 64 \\
\hline Noci & Bari & 14,883 & 100 \\
\hline Ostuni & Brindisi & 22,382 & 100 \\
\hline Polignano a Mare & Bari & 6216 & 99 \\
\hline Putignano & Bari & 9913 & 100 \\
\hline Taranto & Taranto & 145 & 1 \\
\hline Total surface & & 171,508 & \\
\hline
\end{tabular}


Province of Bari and also includes a small part of the neighbouring Province of Brindisi. It covers an area of 5457 hectares and is between 202 and $376 \mathrm{~m}$ above sea level. It is made up of parts of the towns of Monopoli, Castellana Grotte, Alberobello and Locorotondo in the Province of Bari and Fasano in the Province of Brindisi.

The SCI area is also characterised by a strong integration of agroecosystems of notable landscape, natural and environmental quality and by a high spatial density of trulli. With regards to this latter feature, the Management Plan of SCI Murgia of Trulli, approved by DGR no. 1615 of 08/09/2009 (Puglia Region, 2009) shows an average spatial concentration estimated at 40 trulli/ $/ \mathrm{km}^{2}$ that is approximately half of the maximum values found in the centre of the Valley of Itria (70-90 trulli/km²). The Management Plan, therefore, recognises the trulli buildings situated in SCI to have not only an aesthetic and architectural value but also historical, anthropological and agro-environmental protection requirements.

Therefore, the trulli play a central role in the protection and enhancement of the Murgia dei Trulli. Detailed knowledge of this phenomenon can be a preparatory tool for their conservation and their architectural and functional re-use.

\section{Study setting}

The analysis of the trulli spatial distribution and their close connection with the agro-environmental and socioeconomic specificity has focused on a succession of phases.

In the first phase, the most suitable base map has been chosen to find trulli buildings and agro-environmental, hydrogeological, architectural, archaeological, social infrastructural components that characterise the SCI territory.

The following map material was used.

- Digital colour orthophoto at a scale of 1:5.000 with a pixel ground resolution of $50 \mathrm{~cm}$ obtained from an aerial flight performed in 2006 .

- 1:2.000 land registry office maps of the towns included in the Murgia of Trulli territory.

- Land use map of the Region of Apulia at a scale of 1:5.000 with legend complying with the European CORINE Land Cover Changes Database.

- Map of the landscape constraints of the Regional Thematic Territorial Urban Plan for the Landscape at a scale of 1:25.000 (PUTT/p, Puglia Region 2000).

- Regional technical map (CTR) at a scale of 1:5.000.

- Hydrogeomorphologic map of the Region of Apulia at a scale of 1:25.000.

- Geolithological map of the Region of Apulia at a scale of 1:100.000.

- Census areas maps of the National Institute of Statistics (ISTAT, 2001).

The maps used were placed in the WGS84 UTM Zone 33N reference system and used in a GIS environment with the support of ESRI
ArcMap10 software.

In the second phase, the trulli located in the SCI area have been identified with their aggregation characteristics (number of cones from which they are composed): after verifying the absence of trulli in the CTR, the methodology used was the interpretation of the digital orthophoto and land registry office maps. A punctual thematic shape file trulli with the attribute table to indicate the number of cones of each individual building was then created. The density analysis function of ArcMap was used to determine the trulli spatial density.

The third phase analysed the relationship between the trulli buildings and the territorial context that characterises the study area, i.e. contemporary land use, agricultural activities, lithological, hydrography, hydraulic hazard areas, road infrastructure, cultural and environmental heritage, resident population, agricultural workers. Methodologically speaking, geoprocessing operations were carried out (clip and buffer) between the trulli shape and the vector data in the mapping used.

Specifically, the relationships between actual land use, spatial distribution of the trulli and their aggregation characteristics have been identified through the intersection (clip) of the trulli shape with the land use thematic map that constitutes an effective tool to gain knowledge of the territory and vegetation coverage of the agroforestry surfaces. The relationship between trulli buildings and landscape-environmental components of the Murgia dei Trulli were analysed by creating buffers on the archaeological, architectural and environmental heritage identified by the PUTT/p of the Region of Apulia (Puglia Region,

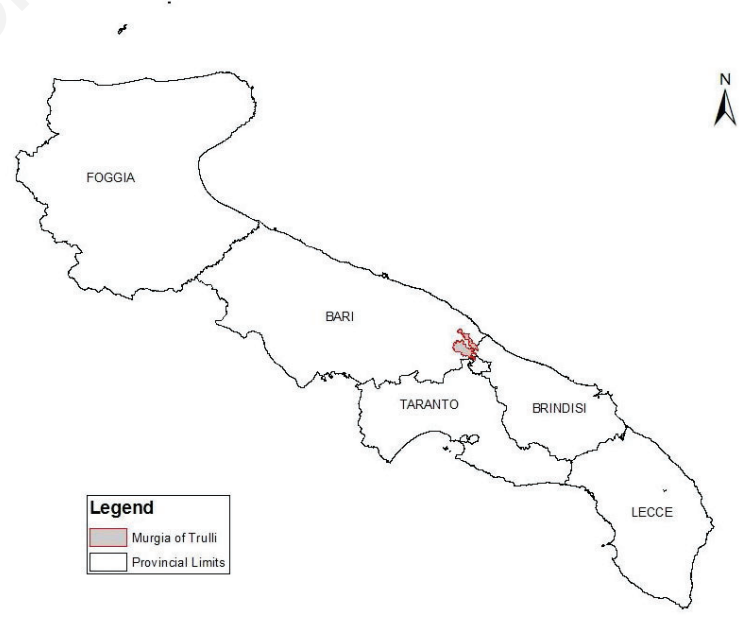

Figure 1. Site of community importance Murgia of Trulli in the Apulia Region.

Table 2. Municipalities included in site of community importance Murgia of Trulli.

\begin{tabular}{|c|c|c|c|}
\hline Municipalities & Province & $\begin{array}{c}\text { Surface within the Murgia } \\
\text { of Trulli, ha }\end{array}$ & $\begin{array}{l}\text { Surface within the Murgia of } \\
\text { Trulli/municipal total area, \% }\end{array}$ \\
\hline Alberobello & Bari & 538.8 & 13 \\
\hline Castellana Grotte & Bari & 1068.8 & 16 \\
\hline Fasano & Brindisi & 233.8 & 2 \\
\hline Locorotondo & Bari & 57.3 & 1 \\
\hline Monopoli & Bari & 3558.3 & 23 \\
\hline Total surface & & 5457.0 & \\
\hline
\end{tabular}


2000). This methodology was used to identify the trulli that are situated within a $1 \mathrm{~km}$ buffer zone from the territorial resources identified by PUTT/p (Puglia Region, 2000) in order to obtain useful information for the preservation and enhancement of the landscape and of historicalcultural identity. Other buffer zones ( $5 \mathrm{~km}$ and $2 \mathrm{~km}$ ) were used to assess the proximity of the trulli to road infrastructures identified from the regional technical map.

The relationship between the trulli and hydrogeological and geolitologiche components were examined by overlapping the trulli shapes with the regional hydrogeomorphological and geolithological maps. These maps provide information about the lithological, morphological and hydrographic components of the territory and are useful to integrate the hydrological and geo-environmental dynamics with planning and programming choices for the future structure of the territory.

The socioeconomic characteristics of the study area were analysed by identifying the ISTAT census sections presented in the SCI Murgia of Trulli and through consultation of the related ISTAT census database (ISTAT, 2001).

The analysis of the trulli and of the SCI territory, carried out within a GIS environment, was validated by sample field surveys and inspections.

\section{Results and discussion}

The data collected through the cartographic and surveys analysis provided typological (functional and structural), agro-environmental and territorial information about the trulli buildings. Spatial analysis conducted in a GIS environment allowed us to locate and geo-reference trulli and categorise them by the number of cones, the agricultural use of the land belonging to them, the distance from points of cultural and environmental interest and the principal roads (both provincial and main roads). Indeed, thematic maps were elaborated to represent the trulli divided by the number of cones and in relation to agro-environmental and territorial components.

The interpretation of local land registry maps and digital orthophoto identified 587 trulli buildings within the SCI distinguishing them according to the number of cones they had (Table 3 and Figure 2). With reference to the aggregative types, we found that monocellular buildings are the most prevalent (31.5\%) followed by bicellular (22\%). There are also a significant number (30\%) of buildings with 3 and 4 cones
(16.7\% and $13.3 \%$, respectively) while only a small number of buildings have more than 5 cones (16.5\%).

The overall number of trulli buildings represents $30 \%$ of the houses found in the SCI; the 2001 ISTAT census showed there are approximately 2000 houses in the study area with 3000 residents. Only $42 \%$ of the houses are permanently inhabited by the resident population and the remaining are uninhabited or used for purposes closely related to agriculture. With regards to trulli spatial density, there was an average 10 trulli buildings per square kilometer but there was a high variability within the SCI area with some areas characterised by a high density of such buildings (Figure 3 ).

The trulli density is strongly correlated with the use of the land belonging to them and this has not changed significantly over the years. The analysis of the relationships between land use and trulli buildings shows a close interconnection between their presence, the number of cones and the cultivation system of the land belonging to them (Table 4). With reference to the relationship between trulli buildings and contemporary land use identified by the land use thematic map of the region, the majority of the trulli are to be found in olive grove areas (59\%) and on arable land (14\%). In these areas, the average spatial density is 20 trulli buildings per square kilometer. The main types of trulli buildings in the olive groves are monocellular (36.9\%)

Table 3. Number of trulli buildings according to number of cones.

\begin{tabular}{lcc} 
Number of cones & No. of trulli costructions & $\%$ \\
1 & 185 & 31.5 \\
2 & 129 & 22.0 \\
\hline 3 & 98 & 16.7 \\
4 & 78 & 13.3 \\
\hline 5 & 46 & 7.8 \\
6 & 21 & 3.6 \\
\hline 7 & 19 & 3.2 \\
8 & 6 & 1.0 \\
\hline $9-18$ & 5 & 0.9 \\
Total & 587 & 100 \\
\hline
\end{tabular}

Table 4. Trulli buildings divided by number of cones and land use.

\begin{tabular}{|c|c|c|c|c|c|c|c|c|c|c|c|}
\hline \multirow[t]{2}{*}{ Land use } & \multirow[t]{2}{*}{ Surface area, ha } & & \multicolumn{8}{|c|}{ No. of trulli buildings divided by number of cones } & \multirow{2}{*}{$\begin{array}{c}\text { No. of } \\
\text { trulli } \\
\text { buildings }\end{array}$} \\
\hline & & 1 & 2 & 3 & 4 & 5 & 6 & 7 & 8 & $9-18$ & \\
\hline Olive trees & 1686 & 127 & 63 & 63 & 41 & 23 & 11 & 9 & 6 & 1 & 344 \\
\hline Residential tissue & 62 & 15 & 35 & 17 & 14 & 10 & 2 & 4 & 0 & 1 & 98 \\
\hline Arable & 1787 & 13 & 16 & 14 & 12 & 9 & 8 & 5 & 0 & 3 & 80 \\
\hline Temporary and permanent crops & 103 & 10 & 3 & 1 & 6 & 1 & 0 & 1 & 0 & 0 & 22 \\
\hline Woods & 1370 & 2 & 8 & 0 & 1 & 0 & 0 & 0 & 0 & 0 & 11 \\
\hline Pastures & 145 & 3 & 2 & 1 & 1 & 2 & 0 & 0 & 0 & 0 & 9 \\
\hline Areas of natural recolonisation & 35 & 9 & 0 & 0 & 0 & 0 & 0 & 0 & 0 & 0 & 9 \\
\hline Bushes and shrubs & 53 & 4 & 1 & 0 & 0 & 0 & 0 & 0 & 0 & 0 & 5 \\
\hline Vineyards & 71 & 1 & 0 & 1 & 1 & 0 & 0 & 0 & 0 & 0 & 3 \\
\hline Meadows and wooded pastures & 30 & 1 & 1 & 0 & 0 & 0 & 0 & 0 & 0 & 0 & 2 \\
\hline Others & 98 & 0 & 0 & 1 & 2 & 1 & 0 & 0 & 0 & 0 & 4 \\
\hline Total & 5440 & 185 & 129 & 98 & 78 & 46 & 21 & 19 & 6 & 5 & 587 \\
\hline
\end{tabular}


and those with 2-3 cones (36.6\%). Instead, on arable land most of the trulli buildings have 2-3 (53.1\%) or 4 or more (46.3\%) cones.

These aggregative differences are attributable to the relationship between agricultural crops and animal husbandry. The aggregation of trulli allowed zootechnical activities to be carried out, although these were modest, because they provided a permanent residence for the farmers and guaranteed shelter for livestock. On the other hand, the olive groves do not require the permanent presence of the farmers and the single cone trulli can be used to store agricultural tools and provide living accommodation during the seasonal farming activities (pruning, harvesting, etc.). The connection between trulli and agricultural land use is confirmed by the presence of 71 trulli buildings with more than 4 cones (16.7\% of those present in the SCI area) combined with service agricultural buildings such as barns, stables, silos, warehouses, vehicle shelters and drying barns. The close relationship between trulli and agro-livestock has been highlighted by a negligible presence of trulli buildings in wooded areas and in more natural habitats.

Within the SCI we also found 98 trulli buildings (17\%) situated in isolated residential areas. These buildings have a residential and agricultural function and are often inhabited by the owners of surrounding farms or used as holiday homes.

Concerning the distance of the trulli from points of cultural and environmental interest identified by PUTT/p (Puglia Region, 2000), the study has shown that all trulli buildings situated in SCI area are well within $1 \mathrm{~km}$ of environmental resources (coniferous and deciduous) and 94 trulli buildings (16\%) are located within $1 \mathrm{~km}$ of archaeological and architectural sites: Monte S. Nicola (Monopoli), St. Michael's Church (Monopoli), Masseria Monte del Vento (Castellana Grotte), Masseria Iorello (Monopoli), Masseria Carmelio (Alberobello), Masseria Marzalossa (Monopoli) (Figure 4). These farms are made up

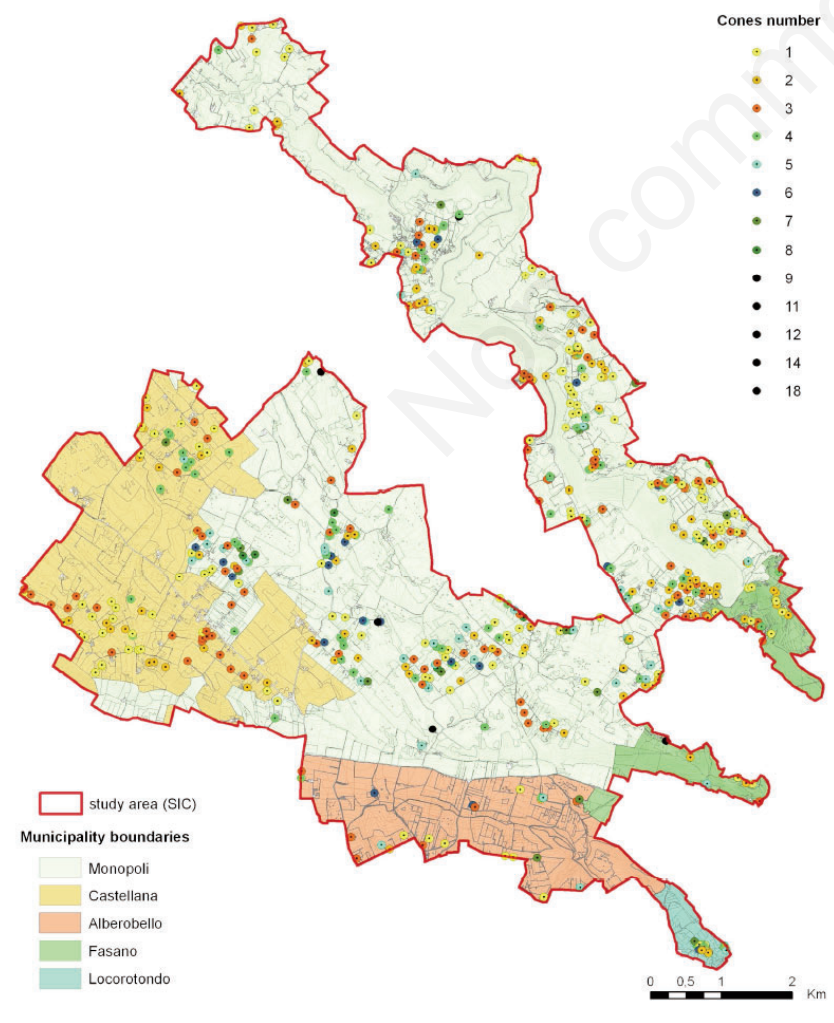

Figure 2. Territorial distribution of the trulli buildings divided by number of cones. of multicellular trulli and rural service building annexes which are, however, included in the 597 trulli identified within the SCI.

The territory of the SCI is crossed by a widespread network of provincial and municipal roads and is located a few kilometers from the N16 national highway. The cartographic processing technique based on the technical regional map shows that $84 \%$ of the trulli buildings in the SCI area are well within $5 \mathrm{~km}$ from the national highway and $97 \%$ are well within $2 \mathrm{~km}$ from provincial roads. The proximity of the trulli buildings to the main communication routes also support their use as homes for people not employed in the agricultural sector $(41 \%$ of whom reside permanently in the SCI) who can easily reach the nearby towns.

The relationship between trulli and morphological, hydrographic and lithological components was identified by the hydrogeomorphological and lithological map. From a lithological point of view, the SCI area is characterised predominantly by limestone on which the trulli were built and, to a lesser extent, by the presence of loose deposits with a prevailing pelitic component on which no trulli buildings were built.

The SCI area is crossed by a dense hydrographic network that is only affected by the presence of surface water during intense rainfall events. It is almost entirely characterised by endorheic final delivery (natural depressed area) subject to floods. The trulli present in the SCI area do not interfere with the rainwater flow in the river floodplains (Figure 5) of and with final deliveries and they are not, therefore, exposed to the risk of flooding.

Thus, the settlement of the trulli in the study territory was carried out in compliance with the hydrogeological system. This protects the trulli and agricultural activities from flood damage and ensures the safety of both the permanent and temporary population.

These conditions of equilibrium between building and territorial components can facilitate the renewals of buildings that is often

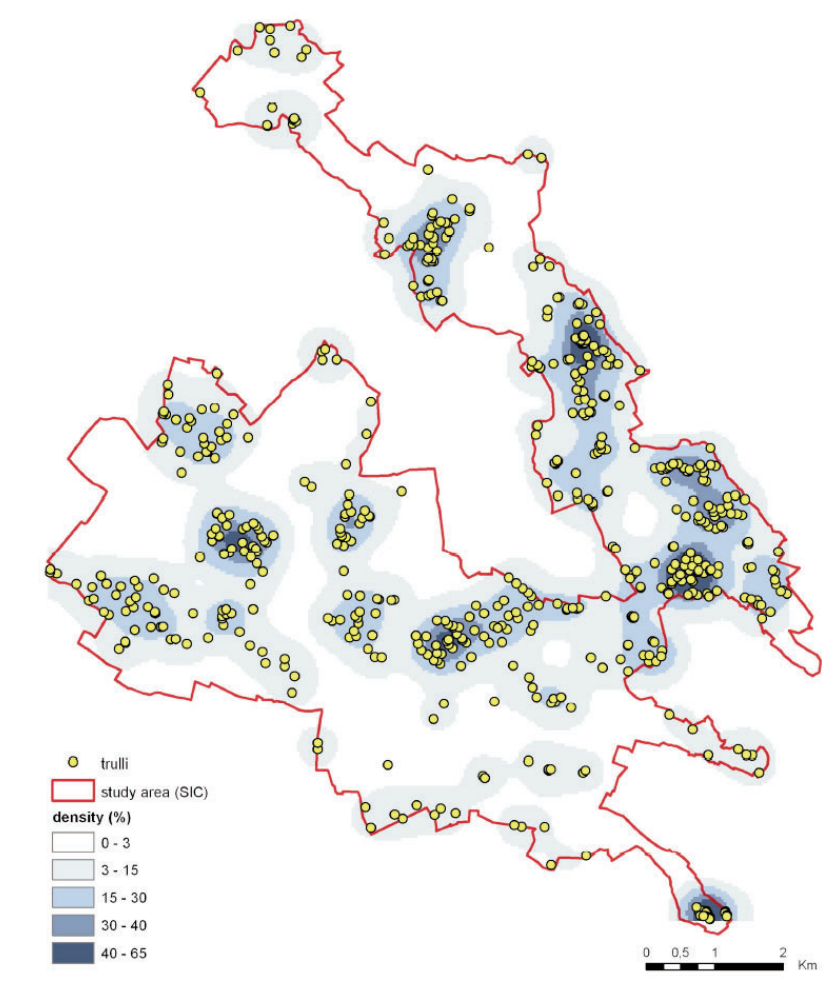

Figure 3. Density of trulli contructions. 
required to ensure the trulli comply to comfortable living standards, to maintain the agro-livestock activities and to establish rural tourism.

\section{Conclusions}

This research shows the results of the analysis of trulli buildings in the SCI Murgia dei Trulli aimed to capture preparatory data for the definition of criteria for the protection of this important architectural heritage. This analysis was conducted using a systematic and efficient method based on a careful territorial reading of the SCI carried out in a GIS environment and integrated with field surveys.

The research has revealed the number, type and spatial distribution of the trulli, the land use of the annexed land, the hydrogeological conditions of the area and the distance of the individual trulli buildings from the road infrastructure and from sites of cultural and environmental interest. The data collected will be used to set-up a decision support system based on multi-criteria analysis to define suitable scenarios for re-use of trulli. The cartography analysis also allowed a computerised and georeferenced archive of trulli buildings in the area SCI to be created, showing typological characteristics and relationships with the agro-environmental and territorial features. The results show that, in this protected area, the high concentration of trulli integrates with the high naturalistic value of the SCI and the traditional agricultural vocation. Thanks to the close link between agriculture and trulli, their protection and enhancement cannot be separated from the tutelage of the agricultural landscape and the promotion of agriculture. Currently, in fact, approximately $20 \%$ of the resident population in the SCI is

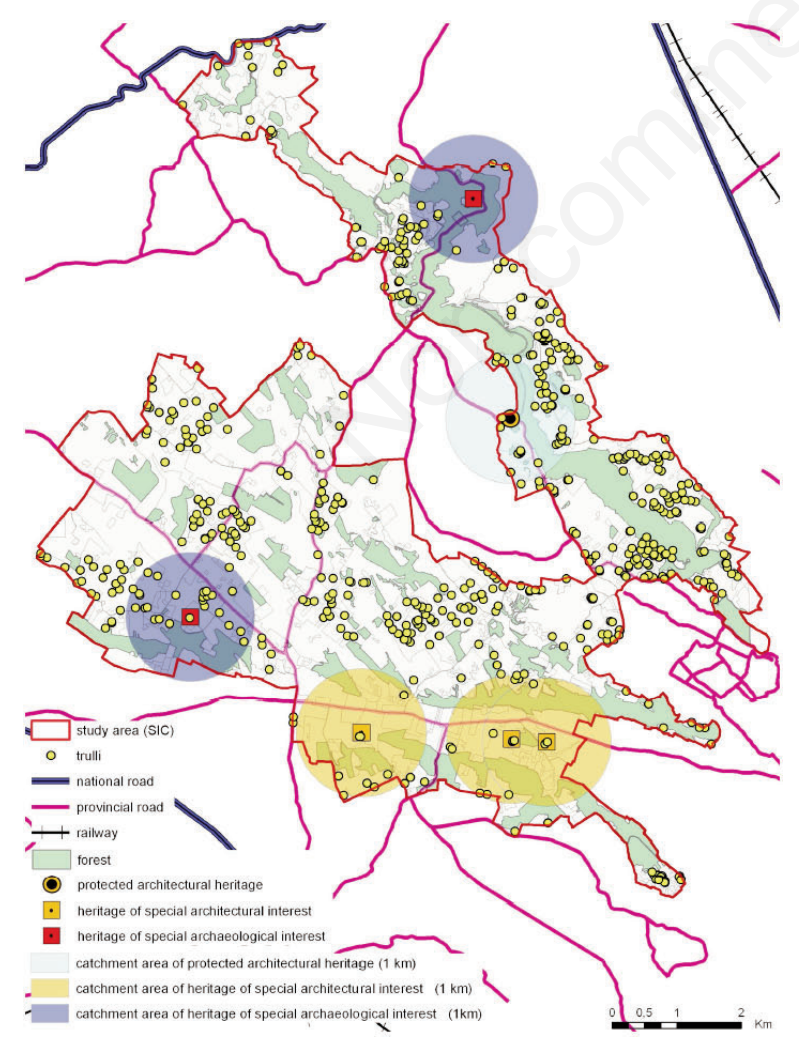

Figure 4. Relationship between trulli and cultural and environmental heritage. employed in the agricultural sector. It is, therefore, necessary to protect the olive groves through legislative and planning tools, enhance olive oil production and encourage cultivation of arable crops through systems of support for sustainable agriculture. The abandonment of agricultural practices may otherwise determine the abandonment of trulli buildings and could have negative effects on landscape conservation due to the potential progressive colonisation of the Mediterranean vegetative species.

The conservation, appropriate recovery and enhancement of the trulli is, however, required to avoid the negative visual impact caused by their degradation and to enhance or renew the sustainable cultivation of land in order to protect SCI habitats that are of high natural value. In this territorial context, initiatives for the protection, recovery and reuse of the trulli are, therefore, of a general public interest for their conservation, for the protection of the agricultural landscape and agroenvironment components and to encourage the development of local rural economies, creating employment and maintaining the resident and/or seasonal population. A basic principle for the protection of the trulli is to use them for activities similar to those for which they were originally designed and built. For this reason, the difficulties faced in attempts to re-use trulli may be overcome by promoting agricultural activities. The use of the trulli buildings for purposes related to agriculture would respect their identity and would preserve the traditional rural vocation of the territory. In addition, trulli may be used as cultural containers (museums of agriculture, information points, educational farms) or for tourist purposes (hotels, holiday cottages, restaurants). Such an approach would help design and create new life cycles for the trulli while respecting their identity and the context in which they are located, and ensure that this building and agro-environmental heritage is preserved for future generations.

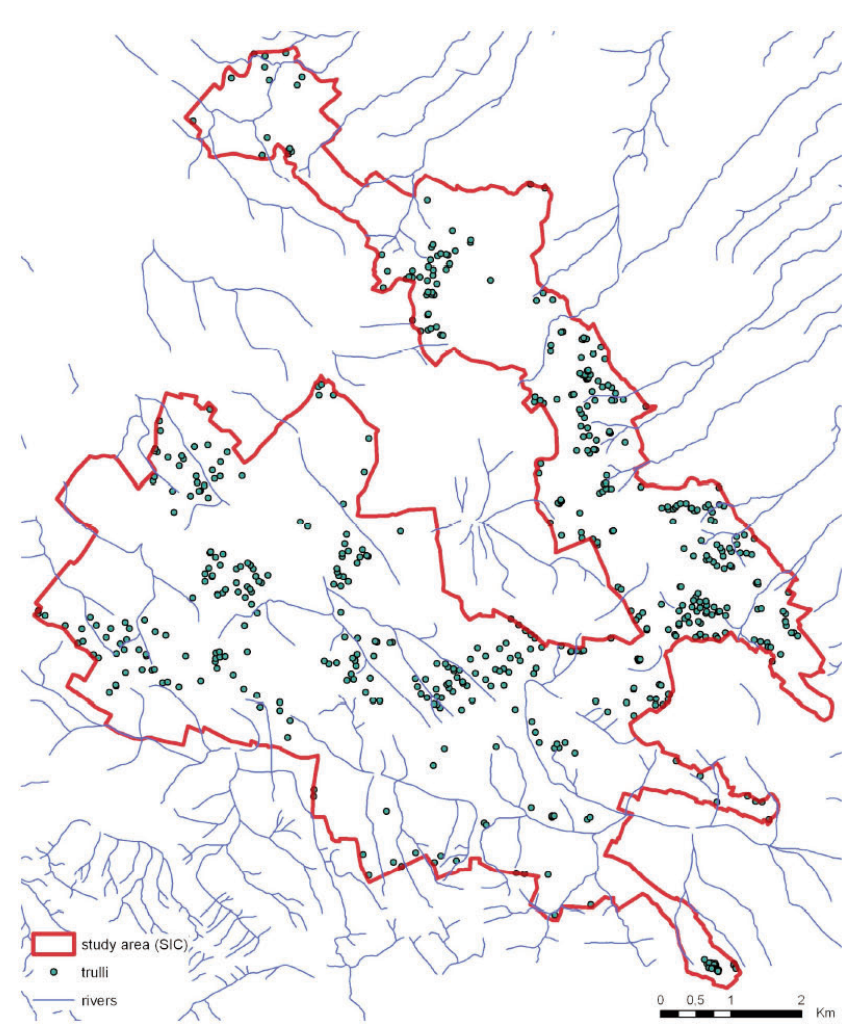

Figure 5. Relationship between trulli and river. 


\section{References}

Ambrosi A., Degano E., Zaccaria C. 1990. Atti I Semin. Int. "Architettura in pietra a secco". Schena Editore, Fasano, Italy.

Allen E. 1984. Pietre di Puglia: Dolmen, trulli e insediamenti rupestri. Adda Editore, Bari, Italy.

Banks I., MacGregor G. 2000. Townships to farmsteads: rural settlement studies in Scotland, England and Wales. British Series: 293. British Archaeological Reports, Oxford, UK.

Calò F. 2007. Ripari trulliformi in pietra a secco nel Salento. Progeca, Tricase, Italy.

Cardinale N., Rospi G., Stefanizzi P. 2013. Energy and microclimatic performance of Mediterranean vernacular buildings: the Sassi district of Matera and the Trulli district of Alberobello. Build. Environ. 59:590-8.

D’Aurea V. 2008. I trulli di Polignano a Mare (BA). Costruzioni a secco e società moderna: la sfida della conservazione. Boll. Ing. 11:3-23.

Dal Sasso P., Giglio G., 1994. Metodologie per il recupero di particolari costruzioni rurali: i trulli. Atti IV Semin. II Ed. AIGR "Il recupero dell'edilizia rurale nel contesto territoriale", June 13-16, Cagliari, Italy.

Dal Sasso P., Caliandro L.P. 2010. The role of historical agro-industrial buildings in the study of rural territory. Landscape Urban Plan. 96:146-62.

De Mandato M. 1933. La primitività dell'abitare umano. Fratelli Bocca Ed., Milano, Italy.

Italian Regulation. 2000. Decreto 3 aprile 2000 del Ministero dell'Ambiente - Elenco dei siti di importanza comunitaria e delle zone di protezione speciali, individuati ai sensi delle direttive 92/43/CEE e 79/409/CEE. In: Gazzetta Ufficiale Suppl. Ordinario Serie Generale No. 95, 22/04/2000, pp 5-36.

Italian Regulation. 2005. Decreto ministeriale 6 ottobre 2005. Individuazione delle diverse tipologie di architettura rurale presenti sul territorio nazionale e definizione dei criteri tecnico-scientifici per la realizzazione degli interventi, ai sensi della legge 24 dicembre 2003 , n. 378 , recante disposizioni per la tutela e la valorizzazione della architettura rurale. In: Gazzetta Ufficiale No. 238, 12/10/2005, pp 13-4.

Puglia Region. 1996. Deliberazione Della Giunta Regionale 23 luglio 1996, n. 3310. Direttive 92/43/CEE, relativa alla conservazione degli habitat naturali e seminaturali e della flora e della fauna selvatiche, e 74/409/CEE concernente la conservazione degli uccelli selvatici. In: Boll. Uff. Regione Puglia, No. 115, 11/09/2002, pp 86518676.

Puglia Region. 2000. Deliberazione della Giunta Regionale 15 dicembre 2000, n. 1748. P.U.T.T. Piano Urbanistico Territoriale Tematico per il Paesaggio. Approvazione definitiva. In: Boll. Uff. Regione Puglia, No. 6, 11/1/2001, pp 122-6.

Puglia Region. 2009. Deliberazione Della Giunta Regionale 8 settembre 2009, n. 1615. POR Puglia 2000-2006 - Misura 1.6 - Linea di intervento 1.C - Approvazione definitiva del Piano di Gestione del S.I.C. "Murgia dei Trulli" (S.I.C. IT 9120002). In: Boll. Uff. Regione Puglia, No. 148, 22/9/2009, pp 19452-6.

Fuentes J.M., Gallego E., García A.I., Ayuga F. 2010. New uses for old traditional farm buildings: The case of the underground wine cellars in Spain. Land Use Policy. 27:738-48

Giglio G. 1994. Un parco rurale per le capanne di pietra. La Piazza, mensile ostunese, anno VIII, n. 11 novembre 1994.

Giorgi C., Speciale P. 1989. La cultura del trullo. Antologia di scritti letterari e scientifici sui trulli. Schena Editore, Fasano, Italy.

Guercini S., Ruggiero M.L. 2009. Per l'immaginario di un nuovo paesaggio rurale. Atti IX Convegno Nazionale AIIA "Ricerca e innovazione nell'ingegneria dei biosistemi agro-territoriali”, Ischia, Italy.

ISTAT. 2001. Censimento generale della popolazione. ISTAT, Roma, Italy.

Notarnicola G. 1940. I trulli di Alberobello. Unione Editori d'Italia, Roma, Italy.

Pagano G., Guarniero D. 1936. Architettura rurale italiana. Hoepli Ed., Milano, Italy.

Picuno P. 2012. Vernacular farm buildings in landscape planning: a typological analysis in a southern Italian region. J Agricult. Engineer. 43:e20.

Van der Vaart J.H.P. 2005. Towards a new rural landscape: consequences of non-agricultural re-use of redundant farm buildings in Friesland. Landscape Urban Plan. 70:143-52.

Zito V. 2009. Linee guida per la prevenzione degli impatti ambientali. CNR, Istituto per le Tecnologie della Costruzione, Bari, Italy. 